\title{
Developmental regulation of the lung in preparation for life after birth: hormonal and nutritional manipulation of local glucocorticoid action and uncoupling protein-2
}

\author{
M G Gnanalingham, A Mostyn, D S Gardner, T Stephenson \\ and M E Symonds \\ Centre for Reproduction and Early Life, Institute of Clinical Research, University of Nottingham, Nottingham NG7 2UH, UK \\ (Requests for offprints should be addressed to M E Symonds; Academic Division of Child Health, School of Human Development, Queen's Medical Centre, \\ University Hospital, Nottingham NG7 2UH, UK; Email: michael.symonds@nottingham.ac.uk)
}

\begin{abstract}
Glucocorticoid action has a major role in regulating fetal and postnatal lung development, although its impact on mitochondrial development is less well understood. Critically, the consequences of any change in glucocorticoid action and mitochondrial function in early life may not be limited to the postnatal period, but may extend into later life. This paper focuses on more recent findings on the impact of ontogeny, fetal cortisol status, maternal nutrient restriction and postnatal leptin administration on mitochondrial uncoupling protein (UCP)-2, glucocorticoid receptor (GR) and $11 \beta$-hydroxysteroid dehydrogenase type 1 (11ßHSD1) isoform abundance in the lung. For example, in sheep, GR and 11ßHSD1 mRNA are maximal at 140 days' gestation (term $\sim 147$ days), while UCP2 mRNA peaks at 1 day after birth and then decreases with advancing age. In the fetus,
\end{abstract}

chronic umbilical cord compression enhances the abundance of these genes, an outcome that can also be produced after birth following chronic, but not acute, leptin administration. Irrespective of the timing of maternal nutrient restriction in pregnancy, glucocorticoid sensitivity and UCP2 abundance are both upregulated in the lungs of the resulting offspring. In conclusion, prenatal and postnatal endocrine challenges have distinct effects on mitochondrial development in the lung resulting from changes in glucocorticoid action, which can persist into later life. As a consequence, changes in glucocorticoid sensitivity and mitochondrial protein abundance have the potential to be used to identify those at greatest risk of developing later lung disease.

Journal of Endocrinology (2006) 188, 375-386

\section{Introduction}

Mitochondria, the 'powerhouses' of the cell, control the oxidative energy supply in normal and pathological physiology, embryonic development, apoptosis and general body ageing (Gottlieb 2000). While the metabolic regulation of mitochondria is well described, the endocrine and nutritional regulation of specific mitochondrial proteins, particularly during fetal and postnatal development, is less well defined. This is perhaps surprising given the very high metabolic demands on the newborn that have a considerable impact on both lung and mitochondrial function (Symonds et al. 1993, 1995, 2003).

The transition from fetus to neonate represents a major physiological, hormonal and environmental challenge. In order to survive, the fetus must establish independent thermoregulation and ventilation shortly after birth, and this requires a number of highly complex physical and hormonal interactions around the time of parturition. Effective ventilation after birth is dependent on the rapid activation of lung function, which is controlled by a number of hormones during the peripartum period (Grier \& Halliday 2004, Rajatapiti et al. 2005). These help to ensure that there is rapid clearance of lung fluid followed by the entry of air processes, which can occur independently (Olver et al. 2004). Our understanding of the endocrine and nutritional regulation of lung development mainly stems from studies utilising the sheep, undoubtedly the species of choice to investigate these variables. The newborn sheep, like the human infant, has a mature hypothalamic-pituitary-thyroid-adrenal axis at birth, while there is a marked difference in lung development 


\section{inner \\ mitochondrial membrane}

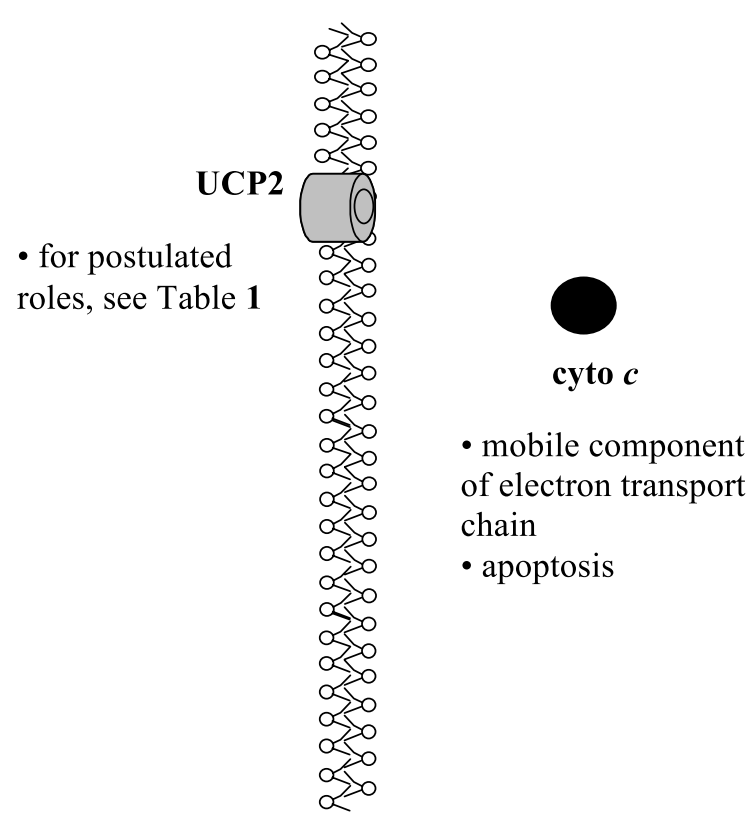

outer

mitochondrial

membrane

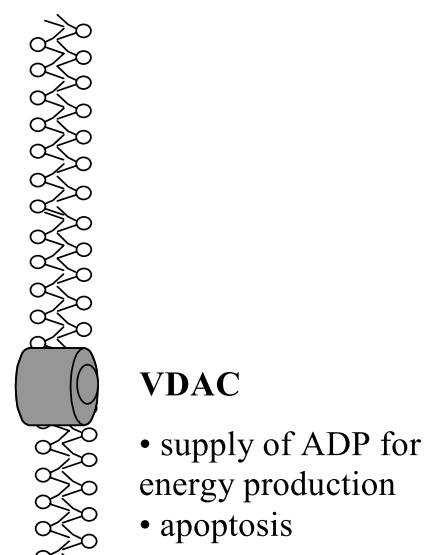

Figure 1 Schematic diagram of mitochondrial protein location and function in the lung. UCP: uncoupling protein; VDAC: voltage-dependent anion channel; cyto c: cytochrome c; ADP: adenosine diphosphate. Adapted from Mostyn et al. (2004).

and mitochondrial abundance between rodents and larger mammals (Gnanalingham et al. 2005a). In sheep, total mitochondrial protein abundance increases during gestation to peak around the time of birth in the majority of tissues, including the lung, studied to date (Mostyn et al. 2003b).

In the following review, we will focus on the effect of age (ontogeny); discrete nutritional and endocrine modulation of specific lung mitochondrial proteins and receptors, namely, uncoupling protein (UCP)-2, voltagedependent anion channel (VDAC), cytochrome $c$; and local glucocorticoid action, as determined by the abundance of glucocorticoid receptor (GR) and isoforms of $11 \beta$-hydroxysteroid dehydrogenase (11ßHSD). The locations and postulated roles of UCP2, VDAC and cytochrome $c$ are outlined in Fig. 1.

\section{Mitochondrial proteins and energy metabolism}

Uncoupling proteins are members of the inner mitochondrial membrane carrier subfamily. UCP2 shares 56\% homology with UCP1 (Erlanson-Albertsson 2003), and is widely expressed in white adipose tissue, lung, spleen, thymus, macrophages, bone marrow, stomach, islets of
Langerhans, skeletal muscle, heart, kidney, placenta and brain (Ricquier \& Bouillaud 2000, Pecqueur et al. 2001). This recognised wide tissue distribution is based primarily on UCP2 mRNA determination, while the localisation of the protein has proved more problematic, mainly because of the lack of antibodies sufficiently sensitive to detect the protein, which, in adults, is present at $1 \%$ of the levels of UCP1 in brown adipose tissue (Erlanson-Albertsson 2003). Using specific antibodies raised against the human sequence, UCP2 protein was primarily located in white adipose tissue, lung, spleen and stomach (Pecqueur et al. 2001). The marked discrepancy in UCP2 mRNA and protein expression potentially reflects the translational regulation of UCP2 mRNA by an upstream open reading frame located in exon 2 of the UCP2 gene, which strongly inhibits the expression of the protein (Pecqueur et al. 2001). Consequently, the exact function of UCP2 remains a subject of intense debate (Nedergaard \& Cannon 2003), with postulated roles in energy balance (Buemann et al. 2001), reactive oxygen species (ROS) production (Negre-Salvayre et al. 1997) and apoptosis (Voehringer et al. 2000), as summarised in Table 1.

Located in the outer mitochondrial membrane, VDAC, an anion selective channel, is considered to be the main 
Table 1 Postulated roles for uncoupling protein-2

Energy regulation
Reactive oxygen species regulation
Apoptosis
Macrophage-mediated immunity
Neuroprotection
Induction of pyrexia

pathway for metabolite and ion diffusion across this membrane due to its propensity to form pores (Colombini 1979). Respiration in mitochondria may be influenced by changes in the permeability of the outer membrane regulated by VDAC (McEnery et al. 1993), although it has a range of functions dependent on tissue location and may also be present in other extramitochondrial membranes (Shinohara et al. 2000). VDAC, along with other membrane proteins, could also be responsible for the release of cytochrome $c$ from the intermembrane space, a process that has been implicated in the chain of events involved in apoptosis (Crompton 1999). Cytochrome $c$ is itself an essential component of the mitochondrial respiratory chain and is a mobile electron transporter, involved in the electron transfer from complexes III and IV of the electron transport chain (Lehninger et al. 1993).

\section{Local glucocorticoid action}

Tissue sensitivity to glucocorticoids is regulated predominantly by intracellular expression of the GR and $11 \beta$ hydroxysteroid dehydrogenase type 1 (11ßHSD1) and type $2(11 \beta \mathrm{HSD} 2)$ at the level of gene transcription. The GR is found in almost every cell in the body and serves a multitude of physiological functions, ranging from glycogen deposition in the liver to inhibition of lymphocyte function (Svec \& Rudis 1981, Sapolsky et al. 1984). Glucocorticoids can modulate their own action, not only by inhibition of the hypothalamic-pituitary axis, but also by a negative feedback downregulation of GR number (Svec \& Rudis 1981, Sapolsky et al. 1984). Changes in GR response can also be important, either at the central nervous system level, by modulating the negative glucocorticoid feedback (De Kloet et al. 1998), or at a peripheral level, by regulating cell differentiation and metabolism in a tissue-specific fashion (Kissebah \& Krakower 1994). The critical importance of the GR in survival after birth is illustrated by mice that lack the GR gene, most of which (>90\%) die at birth from respiratory dysfunction (Cole et al. 1995). Not surprisingly, lung development in terms of its gross structure, as well as

\section{Supporting references}

Boss et al. 2000, Buemann et al. 2001

Negre-Salvayre et al. 1997, Echtay et al. 2002,

Ookawara et al. 2002

Voehringer et al. 2000, Sun \& Zennel 2004

Arsenijevic et al. 2000, Ookawara et al. 2002,

Alves-Guerra et al. 2003

Bechmann et al. 2002, Paradis et al. 2003,

Mattiasson et al. 2004

Faggioni et al. 1998, Diano et al. 2000 epithelial cell structure, is severely retarded in these fetuses (Cole et al. 2004).

In the developing lung, $11 \beta \mathrm{HSD} 1$ and 2 closely follow changes in the GC (Gnanalingham et al. 2005a). $11 \beta$ HSD 1 behaves predominantly as an 11-oxoreductase, utilising nicotinamide adenine dinucleotide (NAD) phosphate as a cofactor to catalyse the conversion of inactive cortisone to bioactive cortisol, and as an intracellular modulator of glucocorticoid excess to the GR (Bamberger et al. 1996, Stewart \& Krozowski 1999). It is widely distributed and present in lung as well as adipose tissue, skeletal muscle, heart, brain and adrenal cortex (Seckl et al. 2004). Conversely, $11 \beta$ HSD2 behaves as an NAD-dependent dehydrogenase, catalysing the inactivation of cortisol to cortisone, and thereby maintains the specificity of the mineralocorticoid receptor for aldosterone (Stewart \& Krozowski 1999). 11ßHSD2 is generally restricted to mineralocorticoid target tissues, such as the kidney, sweat glands, salivary glands and gastric mucosa (Seckl et al. 2004), but is also highly abundant in the lung (Gnanalingham et al. 2005a).

\section{Changes in the lung during fetal and postnatal life}

In man and sheep, the development of lung architecture occurs during fetal and early postnatal life, in four defined phases (embryonic, pseudoglandular, canalicular and alveolar; Fig. 2), which depend partly on intact fetal adrenal and thyroid glands and the associated prepartum surge in fetal plasma cortisol and tri-iodothyronine $\left(T_{3}\right)$ (Symonds \& Clarke 1996, Fowden et al. 1998). In addition, fetal plasma catecholamines, with noradrenaline constituting $40-60 \%$ of total catecholamines in the fetal sheep adrenal gland (Robinson et al. 1983), are needed for increased surfactant production and decreased lung fluid production near term (Phillippe 1983, Wallace et al. 1996). By the time of birth, the airways have been laid down and the formation of alveoli has begun, although it is clear that, at birth, gas exchange may largely take place within terminal air sacs, the predecessors of definitive alveoli. 


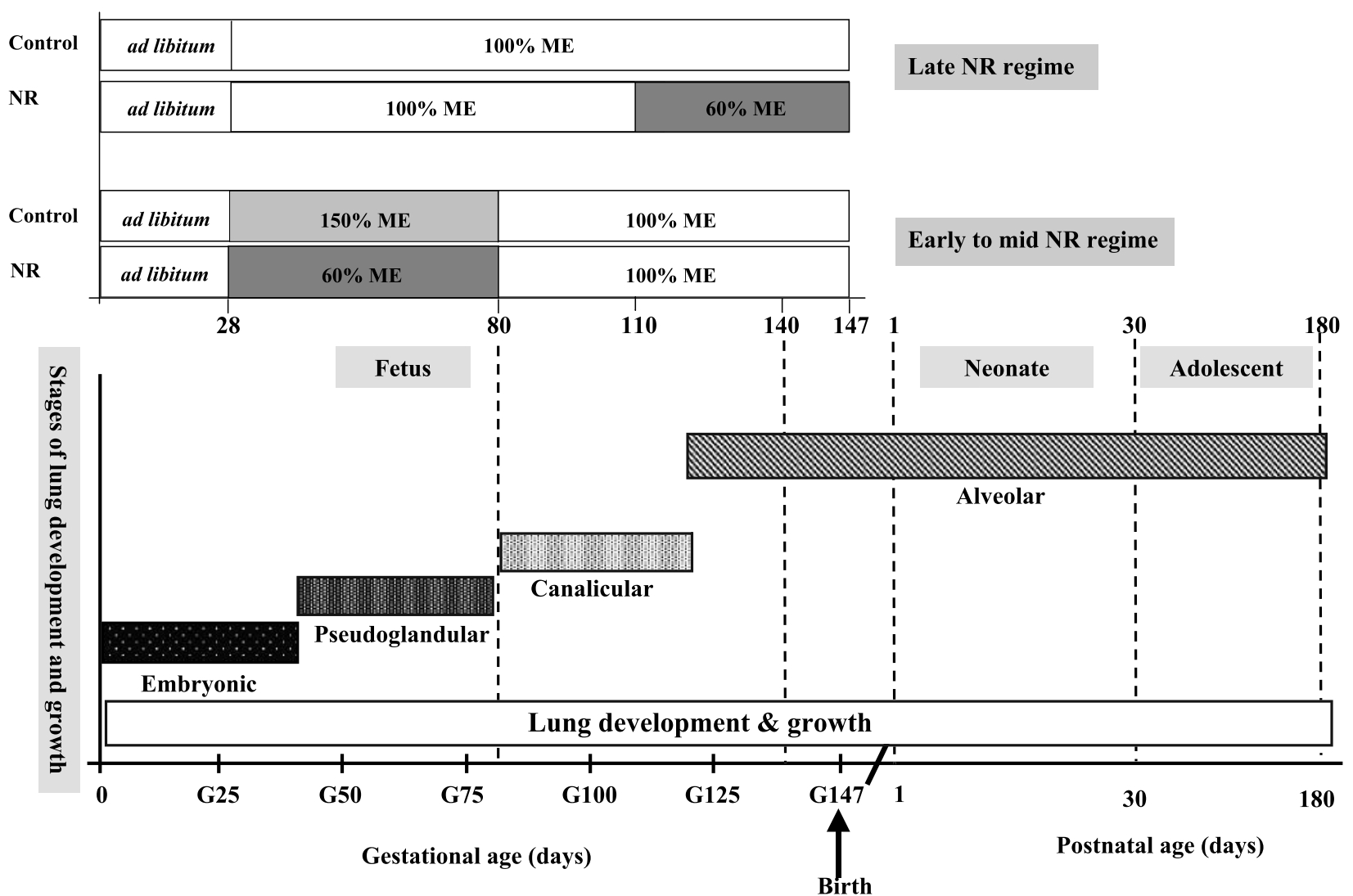

Figure 2 Phases of fetal lung development and postnatal lung growth in relation to the timing of periods of maternal nutrient restriction in the sheep. The phases of fetal lung development are as follows: embryonic, 0-40 days' gestation; pseudoglandular, 40-80 days; canalicular, 80-120 days; alveolar, 120 days to term (148 days). In early to middle (28-80 days' gestation) maternal nutrient restriction (NR), lungs were sampled in the fetus at 80- and 140-day gestation and sheep at 180 days (6 months), while, in late (110-147 days' gestation) maternal NR, lungs were sampled at 1 and 30 days' postnatal age. NR mothers received $60 \%$ of their metabolisable energy (ME) requirements for maternal metabolism and fetal growth; control mothers received 100\% (late gestational NR) to $150 \%$ (early to midgestational NR) ME requirements during the period of NR. G: gestational age. Adapted from Alcorn et al. (1981), Harding (1994) and Gnanalingham et al. (2005b).

After birth, more alveoli are formed until the age of 18-36 months in offspring (Thulbeck 1982), after which lung growth occurs largely by enlargement of existing alveoli. Thus, it is evident that environmental compromises imposed during fetal or early postnatal life, when lung architecture is being laid down, can result in permanent alterations in lung structure that have the potential to affect later function (Harding 1994).

In the fetus, lung growth can be affected by metabolic, endocrine and inflammatory factors affecting the intrauterine environment (Kotecha 2000). These are not mutually exclusive, in that alterations in one may affect others. Indeed, several are associated with intrauterine conditions that lead to low birth weight, by restricting fetal growth and/or leading to preterm birth, including fetal nutrient restriction, fetal hypoxaemia, elevated circulating corticosteroid levels and intrauterine infection (Harding et al. 2000). They also affect mitochondrial protein abundance in the lung (Gnanalingham et al. 2005a, 2005b, Mostyn et al. 2003b).

In the sheep lung, the peak in UCP2 mRNA at day 1 precedes that of the protein at day 7 of age, coinciding with maximal abundance of VDAC, while cytochrome $c$ protein abundance remains unchanged with age (Mostyn et al. 2003b, Gnanalingham et al. 2005a). The developmental ontogeny of UCP2 mRNA in the sheep lung appears to be markedly different from that in the rodent, where the concentration of UCP2 mRNA is low and unchanged during late gestation, doubling within $6 \mathrm{~h}$ after birth and remaining high to adulthood (Xiao et al. 2004). Furthermore, in contrast to rodents (Pecqueur et al. 2001), UCP2 mRNA correlates with protein levels in the postnatal sheep lung (Mostyn et al. 2003b, Gnanalingham et al. 2005a). These changes in UCP2 closely follow the peak abundance in GR and 11ßHSD1 mRNA prior to term, thereby indicating a potential developmental link 


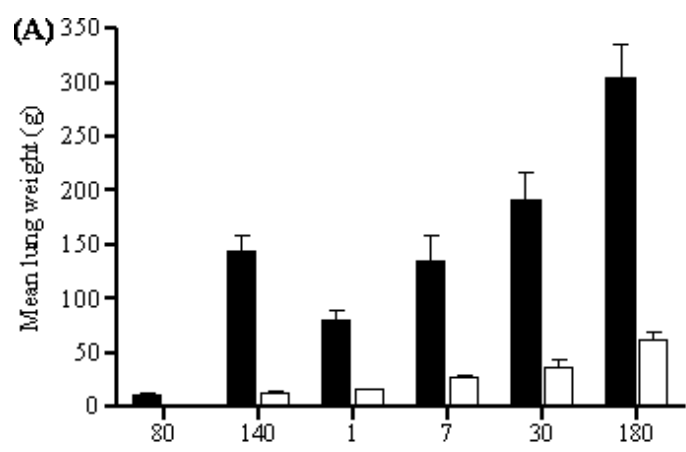

(B)

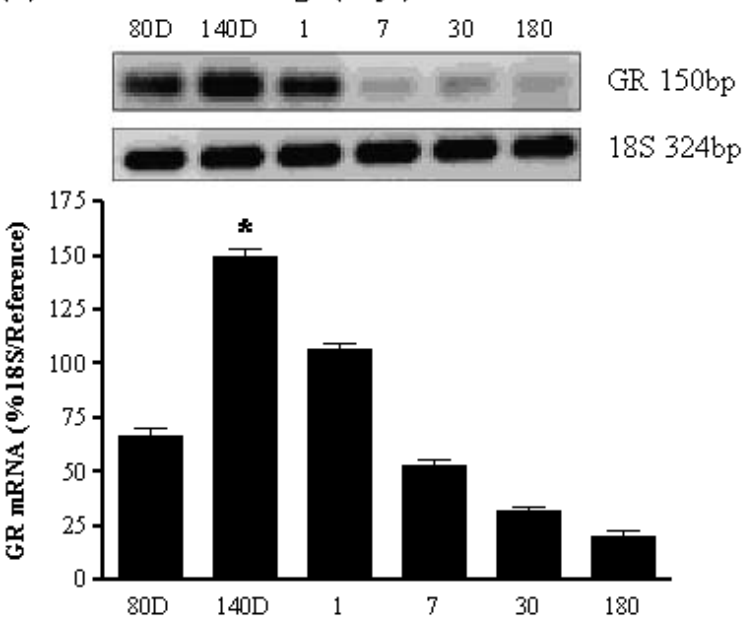

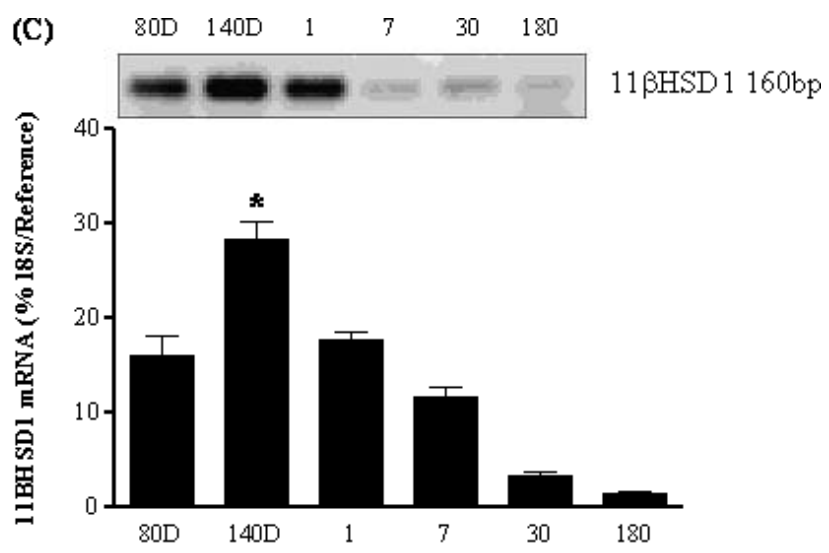

(D) $\begin{array}{llllll}80 \mathrm{D} & 140 \mathrm{D} & 1 & 7 & 30 & 180\end{array}$

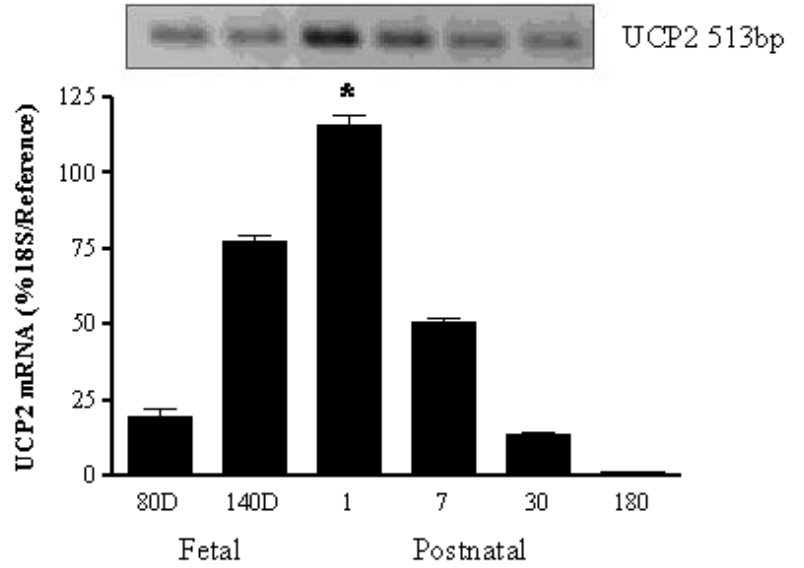

Age (days)

Figure 3 Ontogeny of (A) fresh $\mathbf{\square}$ and dry lung weights $\square$, (B) glucocorticoid receptor (GR) mRNA, (C) 11 $\beta$-hydroxysteroid dehydrogenase type 1 (11ßHSD1) mRNA and (D) uncoupling protein-2 (UCP2) mRNA, between the fetus at 80- and 140-day gestation (term $\sim 147$ days) and 6 months' postnatal age in the sheep lung. Examples of each gene mRNA expression are given. 18S, 18S mRNA. Values are means \pm S.E. $\left(n=6\right.$ per time point). ${ }^{*}$ Maximal abundance detected, significantly different $(P<0 \cdot 01)$ from all other age groups, and greatest at 180 days (6 months). Adapted with permission from Gnanalingham et al. (2005a).

between UCP2 and cortisol (Gnanalingham et al. 2005a) (Fig. 3). Taken together, such findings suggest a potential role for UCP2 and local glucocorticoid action within the lung in the peripartum period, mirroring the developmental ontogeny of brown adipose tissue-specific UCP1, which is primarily involved in non-shivering thermogenesis (Clarke et al. 1997b). A direct thermogenic role for UCP2, however, appears very unlikely, considering the low guanosine diphosphate (GDP)-binding activity in the fetal and postnatal lung, which is approximately $5 \%$ of that found in newborn brown adipose tissue (Gnanalingham et al. 2005a). Potential glucocorticoid and thyroid response elements have been identified in the promoter region of human UCP2 (Tu et al. 1999), suggesting that the developmental ontogeny of UCP2 mRNA expression in the sheep lung could be directly or indirectly regulated by glucocorticoids and thyroid hormones, as is the case for UCP1 (Mostyn et al. 2003a). Indeed, a range of mitochondrial proteins and cellular enzymes in the lung are influenced by the fetal endocrine environment (Mostyn et al. 2003b, Gnanalingham et al. 2005a, 2005b).

\section{Endocrine manipulation of fetal lung mitochondrial development}

During late gestation, a number of metabolic hormones have significant effects on fetal lung mitochondrial maturation, although cortisol appears to be the most important. For example, fetal plasma cortisol is raised after umbilical cord compression during late gestation (Gnanalingham et al. 2005b). In man, umbilical cord compression occurs 
in up to $40 \%$ of pregnancies and can result from nuchal cord (Capeless \& Clapp 1989), torsion of the umbilicus during gestation (Rayburn et al. 1981), oligohydramnios (Leveno et al. 1984) or compression of the cord during the actual processes of labour and delivery (Wheeler \& Greene 1975). It increases the susceptibility of the fetus to perinatal complications and, potentially, neurodevelopmental handicap (Mann 1986, Capeless \& Clapp 1989). In fetal sheep, partial compression of the umbilical cord to reduce umbilical blood flow by 30\% from baseline for a period of 3 days produces reversible mild fetal asphyxia, a transient increase in fetal plasma adrenocorticotrophic hormone $(\mathrm{ACTH})$ and catecholamines, and a progressive and sustained increase in plasma cortisol, without affecting fetal plasma thyroid hormone concentrations (Gardner et al. 2001, Gnanalingham et al. 2005b). The low fetal arterial $\mathrm{pH}$ and oxygen partial pressure, and increased fetal arterial carbon dioxide partial pressure evident during umbilical cord compression, may affect and/or oppose the ability of cortisol to stimulate thyroid hormone bioavailability (Thomas et al. 1978, Wu et al. 1978).

Chronic umbilical cord compression results in upregulation of UCP2 mRNA, and VDAC and cytochrome $c$ protein abundance with differential effects on local glucocorticoid action and GDP binding (Gnanalingham et al. $2005 b$ ). It causes an increase in $11 \beta$ HSD 1 mRNA, but decreased 11ßHSD2 mRNA abundance and GDP binding in the lung. Furthermore, UCP2, GR and $11 \beta \mathrm{HSD}$ types 1 and 2 mRNA, as well as VDAC and cytochrome $c$ protein abundance, are all significantly correlated with fetal plasma cortisol and catecholamine levels, but not thyroid hormone concentrations, in the fetal lung of umbilical cord compression fetuses (Gnanalingham et al. 2005b). These parallel changes in the mitochondria within fetal lung may better prepare the compromised fetus for preterm birth and extrauterine adaptation by establishing and maintaining effective ventilation. To this extent, VDAC is located within the lung bronchioles of the fetal lung (Yakubu 2005), whereas the exact location of UCP2 remains to be confirmed due to the current unavailability of specific antibodies for ovine UCP2 (Gnanalingham et al. 2005c).

\section{Effects of leptin administration on neonatal lung mitochondrial development}

While it is now established that the fetal endocrine environment affects mitochondrial development in fetal lung, our knowledge of the endocrine milieu postnatally is still limited, despite the fact that this environment affects the extrauterine adaptation necessary to maintain effective ventilation in the neonate (Clarke et al. 1997c). A potential endocrine factor that may be important in lung development is leptin, a $16 \mathrm{kDa}$ polypeptide hormone, principally synthesised and secreted by adipose tissue, which acts to regulate energy homeostasis and a range of neuroendocrine and reproductive functions in the adult (Friedman \& Halaas 1998, Ahima \& Flier 2000). Although the exact role of leptin in the neonate has not been fully established, leptin has been recently implicated in newborn thermogenesis in large mammals (Mostyn et al. 2002, 2004) and in lung growth (Tsuchiya et al. 1999).

Cumulative evidence has identified both fetal and adult lungs as leptin-responsive (Tsuchiya et al. 1999, Henson et al. 2004), and shown that leptin regulates immune function (Loffreda et al. 1998, Lord et al. 1998). UCP2deficient mice are resistant to infection with Toxoplasma gondii, and their macrophages generate $80 \%$ more ROS than wild-type mice and in vitro have fivefold greater toxoplasmacidal activity, which is absent in the presence of a quencher of ROS (Arsenijevic et al. 2000). This proposed role for UCP2 in macrophage-mediated immunity and limitation of ROS has been supported by others (Negre-Salvayre et al. 1997, Ookawara et al. 2002), although this role has not been confirmed in vitro with mitochondria isolated from the lung of UCP2 knockout mice (Couplan et al. 2002).

Decreased abundance of UCP2 plus increased glucocorticoid action in the lung with chronic, but not acute, leptin administration (Gnanalingham et al. 2005c) could promote ROS production and maintain host immunity through augmentation of alveolar macrophage phagocytosis and leukotriene synthesis (Arsenijevic et al. 2000, Mancuso et al. 2002). The impact of a precocious decrease in UCP2 with leptin administration on later lung function has yet to be examined, but it may be important in tissue development, thereby optimising lung function in the neonate. Indeed, it may increase the epithelial response to both inspired air as well as potentially harmful pathogens, although this remains to be examined.

\section{Maternal nutrition and fetal programming of the lung}

At least 30\% of annual deaths in the world are result from cardiovascular disease (CVD), including hypertension, type II diabetes and obesity, as well as lung disease. Extensive epidemiological evidence indicates that the nutritional and hormonal environment encountered by the fetus is a strong determinant of not only fetal growth but also disease risk in later life (Barker 1998, 1999). As a result of these adaptations, infants born to mothers that are nutrient restricted in utero are biologically different from infants born to adequately nourished mothers (Barker $e t$ al. 2001). These epidemiological findings are now strongly supported by experimental animal studies indicating that fetal physiological development and organ sensitivity, including that of the lung, are significantly altered by maternal nutrient restriction (Symonds et al. 1995). Diet type and composition, frequency of feeding, maternal age 


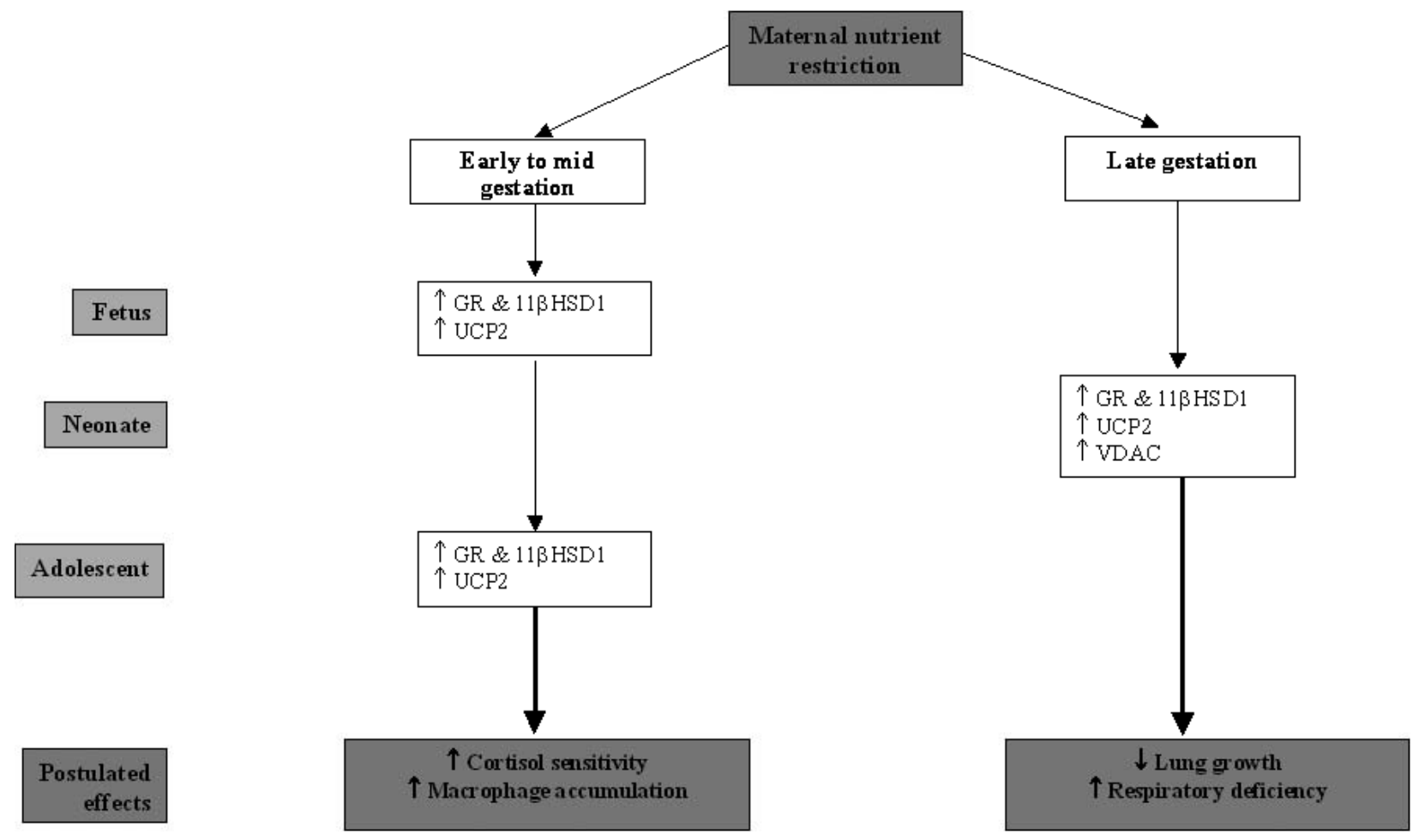

Figure 4 Summary of the effects of early to mid- and late-maternal nutrient restriction on mitochondrial proteins and cellular enzymes in the lung. UCP2: uncoupling protein-2; GR: glucocorticoid receptor; $11 \beta \mathrm{HSD}$ : 11 $\beta$-hydroxysteroid dehydrogenase; VDAC: voltage-dependent anion channel.

and maturity of offspring may further influence these adaptations at birth. Such adaptations have the potential to contribute to a range of diseases, including chronic lung disease, in later life.

\section{Maternal nutrient restriction between early and midgestation}

The Dutch famine of 1944-5 led to one of the most striking epidemiological findings relating to the timing of maternal nutrient restriction and subsequent increase risk of obstructive airways disease in adulthood (Lopuhaa et al. 2000), although those victims that reported a greater incidence of lung disease showed no measurable change in measured lung function. During the 5 -month period of the famine, mean energy intake was $3 \cdot 2 \mathrm{MJ} /$ day compared with $6.3 \mathrm{MJ} /$ day immediately afterward (Roseboom 2000). Dietary restriction during early gestation was shown to have the greatest effect on placental size:birth weight ratio, and to result in a much greater risk of adult CVD, obesity and obstructive airways disease (Lopuhaa et al. 2000, Roseboom et al. 2000a, 2000b), but, to date, the victims' overall rate of mortality has remained unaffected, at least up to 57 years of age (Painter et al. 2005). Interestingly, sheep models of undernutrition that broadly adopt the same magnitude of maternal nutrient restriction as that imposed under the Dutch famine seldom affect birth or tissue weight, but have a pronounced impact on placental mass (Dandrea et al. 2001). The consistent finding that $50 \%$ variation in maternal food intake can determine placental mass may have further relevance to contemporary human populations, for which a similar range between the upper and lower quartiles in energy intake is found in both early and late gestation (Godfrey et al. 1996).

In the sheep lung, maternal nutrient restriction in early to midgestation increased UCP2 mRNA and local glucocorticoid action in the fetus, adaptations that were still evident at 6 months of age (Whorwood et al. 2001, Gnanalingham et al. 2005a) (Fig. 4). Although the exact mechanisms by which maternal nutrient restriction upregulates UCP2 in the lung have yet to be determined, both non-esterified fatty acids (NEFA) and glutathione have postulated roles. In both adult and neonatal rodents, NEFA have been proposed to regulate lung UCP2 mRNA, since calorie restriction causes a rapid increase in NEFA, and lung UCP2 mRNA is increased by NEFA administration to fed animals (Xiao et al. 2004). In sheep, while there is an increase in maternal plasma NEFA between 80 and 140 days' gestation, there are no differences in maternal or fetal plasma NEFA after 80 days' gestation 
following maternal nutrient restriction in early to midgestation (Bispham et al. 2003), and maternal NEFA do not cross the ovine placenta.

Another potential nutritional mediator is glutathione, for which there is a marked reduction in plasma concentrations with starvation (Smith \& Anderson 1992). This may upregulate UCP2 expression in the lung by increasing levels of intracellular ROS (Pecqueur et al. 2001). A similar mechanism has been proposed for the increase in lung UCP2 with lipopolysaccharide injection, whereby macrophage receptors stimulate the production of proinflammatory cytokines, such as tumour necrosis factor (TNF)- $\alpha$ (Clarke et al. 1997a), which activates the nuclear factor- $\mathrm{\kappa B}$ pathway, again increasing levels of intracellular ROS (Pecqueur et al. 2001). It is uncertain, however, what effect glutathione has on the fetus at the time of nutrient restriction, particularly within the lung.

The increase in UCP2 mRNA and local glucocorticoid action that follows maternal nutrient restriction may potentially underlie some of the detrimental effects on fetal and postnatal lung development, although this remains to be fully established. Previous studies of developing animals have shown that both prenatal and early postnatal undernutrition can result in alterations in lung structure and function, with additional adverse effects on respiratory muscle development (Prakash et al. 1993, Sahebjami 1993). After restriction of placental growth, the tracheas of growth-restricted sheep fetuses were found to have thinner mucosal and submucosal layers, reduced ciliation of epithelial cells, and reduced extent of mucosal folding near term (Rees et al. 1991). Children with evidence of growth restriction in utero have reduced forced expiratory flow rates, indicative of impaired airway function (Nikolajev et al. 1998, Magness \& Poston 2005), a condition persisting into adulthood with increased risk of respiratory morbidity and mortality (Barker et al. 1991, Stein et al. 1997). While the molecular bases for these detrimental effects on lung development and function have to be fully elucidated, there is evidence that a cascade of inflammatory markers, including TNF- $\alpha$ and interleukin (IL)-1 $\beta$, which are also known to upregulate UCP2 in the lung (Pecqueur et al. 2001), may underlie the development of chronic lung disease (Ozdemir et al. 1997, Allen 2003). The increased UCP2 mRNA abundance within the lung after maternal nutrient restriction in early to midgestation may predispose to the development of chronic lung disease, especially since UCP2 plays a role in intracellular ROS production (Negre-Salvayre et al. 1997), apoptosis (Voehringer et al. 2000) and macrophage-mediated immunity (Arsenijevic et al. 2000).

\section{Maternal nutrient restriction in late gestation}

Compensatory changes in mitochondrial protein and receptor abundance within the lung after maternal nutrient restriction during late gestation are evident.
VDAC abundance in nutrient-restricted offspring is enhanced up to at least 1 month of age (Mostyn et al. 2003b). There is an accompanying increase in UCP2, GR and $11 \beta \mathrm{HSD} 1 \mathrm{mRNA}$ abundance up to 1 month of age after maternal nutrient restriction in late gestation (Gnanalingham et al. 2005a) (Fig. 4). Interestingly, adaptations of this type in adipose tissue can affect obesity (Seckl et al. 2004); in sheep, they follow the increase in fat mass with age (Bispham et al. 2005). Also in sheep, maternal nutrient restriction in late gestation reduces lung growth (Harding \& Johnston 1995, Symonds et al. 1995) and impairs the growth of the bronchial walls, possibly affecting airway compliance in the immediate postnatal period (Wignarajah et al. 2002). Increased UCP2 mRNA abundance within the lung may underlie the impairment of lung growth and function, by increased intracellular ROS production, activation of macrophages and secretion of proinflammatory cytokines, including TNF- $\alpha$ and IL-1 $\beta$ (Pecqueur et al. 2001, Alves-Guerra et al. 2003). Impaired pulmonary defence mechanisms may result from undernutrition (Bellanti et al. 1997), possibly contributing to greater susceptibility to respiratory infections, especially since the development of mucous elements remains altered in the postnatal lung after restricted fetal growth in late gestation (Wignarajah et al. 2002). The enhanced UCP2 mRNA abundance may also increase susceptibility to infection and death, as demonstrated with Toxoplasma gondii (Arsenijevic et al. 2000).

The mechanism by which maternal nutrient restriction during late gestation affects lung mitochondrial development has yet to be fully determined. Variations in fetal plasma cortisol and thyroid hormones may not be directly responsible for these tissue-specific responses after maternal undernutrition during late gestation. In sheep, maternal cortisol is increased for only the first 10 days of nutrient restriction when food intake is reduced from 110 days' gestation and there is no change in fetal plasma cortisol concentration (Edwards \& McMillen 2001). Although the increase in maternal and fetal plasma thyroxine with gestational age toward term (Fraser \& Liggins 1989, Bispham et al. 2003) may contribute to the ontogenic changes in local glucocorticoid action and UCP2 mRNA abundance within the lung during the peripartum period, both maternal and fetal plasma thyroid hormone concentrations are reduced by maternal nutrient restriction (Rae et al. 2002, Bispham et al. 2003). Hence, the observed changes in local glucocorticoid action and UCP2 mRNA abundance in the lung occur in the absence of any consistent changes in maternal or fetal plasma hormone concentrations after late maternal nutrient restriction.

\section{Conclusion}

Pre- and postnatal challenges have distinct effects on lung mitochondrial development (Fig. 5), which can persist 


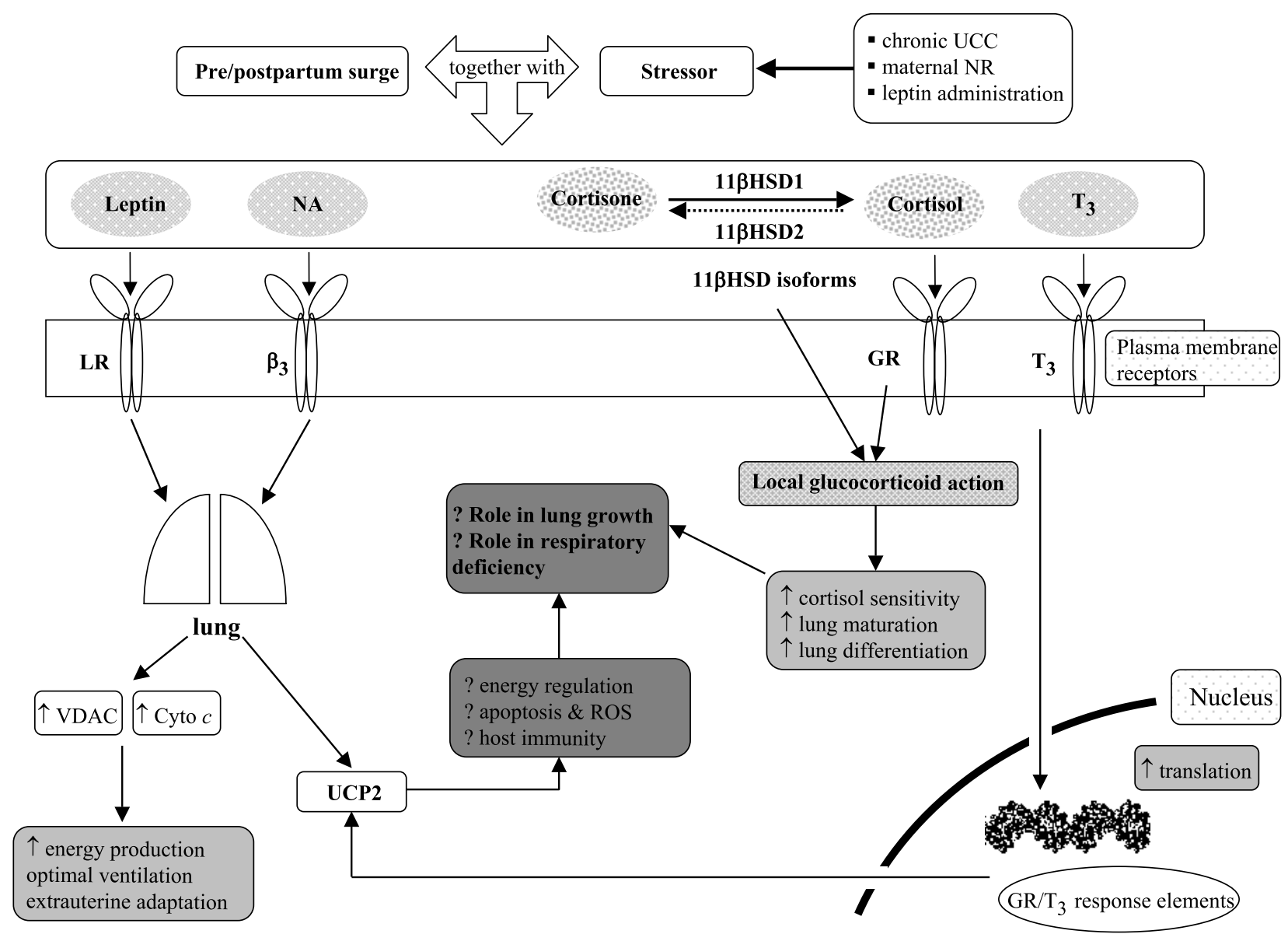

Figure 5 Summary of the main regulators of local glucocorticoid action and UCP2 within the lung. UCC: umbilical cord compression; NR: nutrient restriction; ROS: reactive oxygen species; LR: leptin receptor; GR: glucocorticoid receptor; $\beta_{3}$ : $\beta_{3}$-adrenergic receptor; NA: noradrenaline; $T_{3}$ : tri-iodothyronine; UCP2: uncoupling protein-2; VDAC: voltage-dependent anion channel; cyto c: cytochrome $c$; $11 \beta$ HSD1: $11 \beta$-hydroxysteroid dehydrogenase type 1; 11ßHSD2: $11 \beta$-hydroxysteroid dehydrogenase type 2.

into later life. A greater understanding of the regulation of these mitochondrial proteins and local glucocorticoid action within the lung by endocrine and nutritional factors is likely to be important in preventing neonatal morbidity and mortality. The potential 'programming' of these tissues at the molecular level may underlie the physiological and pathophysiological processes implicated in disease development, including chronic lung disease. Changes in these mitochondrial proteins may therefore provide a potential marker for identifying those most at risk of developing adulthood disease and potential targets of therapeutics.

\section{Acknowledgements}

We thank the Special Trustees for Nottingham University Hospitals and the British Heart Foundation for financial support of this work. The authors declare that there is no conflict of interest that would prejudice the impartiality of this scientific work.

\section{References}

Ahima RS \& Flier JS 2000 Leptin. Annual Review of Physiology 62 413-437.

Alcorn DG, Adamson TM, Maloney JE \& Robinson PM 1981 A morphologic and morphometric analysis of fetal lung development in the sheep. Anatomical Record 201 655-667.

Allen J, Zwerdling R, Ehrenkranz R, Gaultier C, Geggel R, Greenough A, Kleinman R, Klijanowicz A, Martinez F, Ozdemir A, Panitch HB et al. 2003 Statement on the care of the child with chronic lung disease of infancy and childhood. American Journal of Respiratory and Critical Care Medicine 168 356-396.

Alves-Guerra M, Rousset S, Pecqueur C, Mallat Z, Blanc J, Tedgui A, Bouillaud F, Cassard-Doulcier A, Ricquier D \& Miroux B 2003 Bone marrow transplantation reveals the in vivo expression of the mitochondrial uncoupling protein 2 in immune and nonimmune cells during inflammation. Journal of Biological Chemistry $27842307-42312$. 
Arsenijevic D, Onuma H, Pecquer C, Raimbault S, Manning BS, Miroux B, Couplan E, Alves-Guerra M-C, Goubern M, Surwit R et al. 2000 Disruption of the uncoupling protein-2 gene in mice reveals a role in immunity and reactive oxygen species production. Nature Genetics 26 435-439.

Bamberger CM, Schulte HM \& Chrousos GP 1996 Molecular determinants of glucocorticoid receptor function and tissue sensitivity to glucocorticoids. Endocrine Reviews 17 245-261.

Barker DJP 1998 Mothers, Babies and Disease in Later Life, 2nd edn. Edinburgh, UK: Churchill Livingstone.

Barker DJP 1999 Fetal programming and public health. In Fetal Programming: Influences on Development and Disease in Later Life, pp 3-11. Eds PMS O’Brien, T Wheeler \& DJP Barker. London, UK: RCOG Press.

Barker DJP, Godfrey KM, Fall C, Osmond C, Winter PD \& Shaheen SO 1991 Relation of birth weight and childhood respiratory infection to adult lung function and disease from obstructive airways disease. British Medical Journal 303 671-675.

Barker DJP, Forsen T, Uutela A, Eriksson JG \& Osmond C 2001 Size at birth and resilience to effects of poor living conditions in adult life: longitudinal study. British Medical Journal 323 1-5.

Bechmann I, Diano S, Warden CH, Bartfai T, Nitsch R \& Horvath TL 2002 Brain mitochondrial uncoupling protein 2 (UCP2): a protective stress signal in neuronal injury. Biochemical Pharmacology 64 363-367.

Bellanti JA, Zeligs BJ \& Kulszycki LL 1997 Nutrition and development of pulmonary defense mechanisms. Pediatric Pulmonology 16 170-171.

Bispham J, Gopalakrishnan GS, Dandrea J, Wilson V, Budge H, Keisler DH, Broughton Pipkin F, Stephenson T \& Symonds ME 2003 Maternal endocrine adaptation throughout pregnancy to nutritional manipulation: consequences for maternal plasma leptin and cortisol and the programming of fetal adipose tissue development. Endocrinology 144 3575-3585.

Bispham J, Gardner DS, Gnanalingham MG, Stephenson T, Symonds ME \& Budge H 2005 Maternal nutritional programming of fetal adipose tissue development: differential effects on mRNA abundance for uncoupling proteins, peroxisome proliferator activated and prolactin receptors. Endocrinology 146 3943-3949.

Boss O, Hagen T \& Lowell BB 2000 Uncoupling proteins 2 and 3, potential regulators of mitochondrial energy metabolism. Diabetes 49 143-156.

Buemann B, Schierning B, Toubro S, Bibby BM, Sørensen T, Dalgaard L, Pedersen O \& Astrup A 2001 The association between the val/ala-55 polymorphism of the uncoupling protein 2 gene and exercise efficiency. International Journal of Obesity 25 467-471.

Capeless EL \& Clapp JF 1989 Cardiovascular changes in early phase of pregnancy. American Journal of Obstetrics and Gynecology 161 1449-1453.

Clarke L, Bryant MJ, Lomax MA \& Symonds ME 1997a Maternal manipulation of brown adipose tissue and liver development in the ovine fetus during late gestation. British Journal of Nutrition 77 871-883.

Clarke L, Heasman L, Firth K \& Symonds ME $1997 b$ Influence of route of delivery and ambient temperature on thermoregulation in newborn lambs. American Journal of Physiology 272 R1931-R1939.

Clarke L, Buss DS, Juniper DS, Lomax MA \& Symonds ME 1997 c Adipose tissue development during early postnatal life in ewe-reared lambs. Experimental Physiology 82 1015-1017.

Cole TJ, Blendy JA, Monaghan AP, Krieglstein K, Schmid W, Aguzzi A, Fantuzzi G, Hummler E, Unsicker K \& Schutz G 1995 Targeted disruption of the glucocorticoid receptor gene blocks adrenergic chromaffin cell development and severely retards lung maturation. Genes and Development 9 1608-1621.

Cole TJ, Solomon NM, Van Driel R, Monk JA, Bird D, Richardson SJ, Dilley RJ \& Hooper SB 2004 Altered epithelial cell proportions in the fetal lung of glucocorticoid receptor null mice. American Journal of Respiratory, Cell, and Molecular Biology 30 613-619.
Colombini M 1979 A candidate for the permeability pathway of the outer mitochondrial membrane. Nature 279 643-645.

Couplan E, del Mar Gonzalez-Barroso M, Alves-Guerra MC, Ricquier D, Goubern M \& Bouillaud F 2002 No evidence for a basal, retinoic, or superoxide-induced uncoupling activity of the uncoupling protein 2 present in spleen or lung mitochondria. Journal of Biological Chemistry 277 26268-26275.

Crompton M 1999 The mitochondrial permeability transition pore and its role in cell death. Biochemical Journal 341 233-249.

Dandrea J, Wilson V, Gopalakrishnan G, Heasman L, Budge H, Stephenson T \& Symonds ME 2001 Maternal nutritional manipulation of placental growth and glucose transporter-1 abundance in sheep. Reproduction 122 793-800.

De Kloet ER, Vreugdenhil E, Oitzl MS \& Joels M 1998 Brain corticosteroid receptor balance in health and disease. Endocrine Reviews 74 269-301.

Diano S, Urbanski HF, Horvath B, Bechman I, Kagiya A, Nemeth G, Naftolin F, Warden CH \& Horvath TL 2000 Mitochondrial uncoupling protein 2 (UCP2) in the nonhuman primate brain and pituitary. Endocrinology 141 4226-4238.

Echtay KS, Murphy MP, Smith RAJ, Talbot DA \& Brand MD 2002 Superoxide activates mitochondrial uncoupling protein 2 from the matrix side. Studies using targeted antioxidants. Journal of Biological Chemistry 277 47129-47135.

Edwards LJ \& McMillen IC 2001 Maternal undernutrition increases arterial blood pressure in the sheep fetus during late gestation. Journal of Physiology 533 561-570.

Erlanson-Albertsson C 2003 The role of uncoupling proteins in the regulation of metabolism. Acta Physiologica Scandinavica 178 405-412.

Faggioni R, Shigenaga J, Moser A, Feingold KR \& Grunfeld C 1998 Induction of UCP2 gene expression by LPS: a potential mechanism for increased thermogenesis during infection. Biochemical and Biophysical Research Communications 244 75-78.

Fowden AL, Li J \& Forhead AJ 1998 Glucocorticoids and the preparation for life after birth: are there long-term consequences of the life insurance? Proceedings of the Nutrition Society 57 113-122.

Fraser M \& Liggins GC 1989 The effect of cortisol on thyroid hormone kinetics in the ovine fetus. Journal of Developmental Physiology 11 207-211.

Friedman JM \& Halaas JL 1998 Leptin and the regulation of body weight in mammals. Nature $395763-770$.

Gardner DS, Fletcher AJW, Fowden AL \& Giussani DA 2001 Plasma $\mathrm{ACTH}$ and cortisol concentrations during acute hypoxemia following a reversible period of adverse intrauterine conditions in the late gestation ovine fetus. Endocrinology 142 589-598.

Gnanalingham MG, Mostyn A, Dandrea J, Yakubu DP, Symonds ME \& Stephenson T 2005a Ontogeny and nutritional programming of uncoupling protein-2 and glucocorticoid receptor mRNA in the ovine lung. Journal of Physiology 565 159-169.

Gnanalingham MG, Giussani DA, Sivathondan P, Forhead AJ, Stephenson T, Symonds ME \& Gardner DS 2005b Chronic umbilical cord compression results in accelerated maturation of lung and brown adipose tissue in the sheep fetus during late gestation. American Journal of Physiology 289 E456-E465.

Gnanalingham MG, Mostyn A, Webb R, Keisler DH, Raver N, Alves-Guerra MC, Pecqueur C, Miroux B, Symonds ME \& Stephenson T 2005c Differential effects of leptin administration on the abundance of uncoupling protein-2 and glucocorticoid action during neonatal development. American Journal of Physiology 289 E1093-E1100.

Godfrey K, Robinson S, Barker DJP, Osmond C \& Cox V 1996 Maternal nutrition in early and late pregnancy in relation to placental and fetal growth. British Medical Journal 312 410-414.

Gottlieb RA 2000 Mitochondria: execution central. FEBS Letters $4826-12$. 
Grier DG \& Halliday HL 2004 Effects of glucocorticoids on fetal and neonatal lung development. Treatments in Respiratory Medicine $3295-306$

Harding JE \& Johnston BM 1995 Nutrition and fetal growth. Reproduction, Fertility, and Development 7 539-547.

Harding R 1994 Development of the respiratory system. In Textbook of Fetal Physiology, pp 140-167. Eds GD Thorburn \& R Harding. Oxford, UK: Oxford University Press.

Harding R, Cock ML, Louey S, Joyce BJ, Davey MG, Albuquerque CA, Hooper SB \& Maritz GS 2000 The compromised intra-uterine environment: implications for future lung health. Clinical and Experimental Pharmacology and Physiology 27 965-974.

Henson MC, Swan KF, Edwards DE, Hoyle GW, Purcell J \& Castracane VD 2004 Leptin receptor expression in fetal lung increases in late gestation in the baboon: a model for human pregnancy. Reproduction 127 87-94.

Kissebah AH \& Krakower GR 1994 Regional adiposity and morbidity. Physiological Reviews $\mathbf{7 4}$ 761-811.

Kotecha S 2000 Lung growth: implications for the newborn infant. Archives of Disease in Childhood - Fetal and Neonatal Edition 82 F69-F74.

Lehninger AL, Nelson DL \& Cox MM 1993 Oxidative phosphorylation and photo-phosphorylation. In Principles of Biochemistry, pp 542-597. Ed E Geller. New York, NY, USA: Worth.

Leveno KJ, Quirk JG, Cunningham FG, Nelson SD, Santo-Ramos R, Toofanian A \& Depalma RT 1984 Prolonged pregnancy. I. Observations concerning the causes of fetal distress. American Journal of Obstetrics and Gynaecology 150 465-473.

Loffreda S, Yang SQ, Lin HZ, Karp CL, Brengman ML, Wang DJ, Klein AS, Bulkley GB, Bao C, Noble PW et al. 1998 Leptin regulates proinflammatory immune responses. FASEB Journal 12 57-65.

Lopuhaa CE, Roseboom TJ, Osmond C, Baker DJP, Ravelli ACJ, Bleker OP, van der Zee JS \& van der Meulen JHP 2000 Atopy, lung function, and obstructive airways disease after prenatal exposure to famine. Thorax $\mathbf{5 5} 555-561$.

Lord GM, Matarese JK, Howard RJ, Baker SR, Bloom SR \& Lechler RI 1998 Leptin modulates the T-cell immune response and reverses starvation-induced immunosuppression. Nature 394 897-898

Magness RR \& Poston L 2005 Molecular, cellular and endocrine signalling in the perinatal cardiovascular system: interplay and developmental programming. Journal of Physiology $5651-2$.

Mancuso P, Gottschalk A, Phare SM, Peters-Golden M, Lukacs NW \& Huffnagle GB 2002 Leptin-deficient mice exhibit impaired host defense in Gram-negative pneumonia. Journal of Immunology $1684018-4024$.

Mann LI 1986 Pregnancy events and brain damage. American Journal of Obstetrics and Gynaecology 155 6-9.

Mattiasson G, Shamloo M, Gido G, Mathi K, Tomasevic G, Yi S, Warden CH, Castilho RF, Melcher T, Gonzalez-Zulueta M et al. 2004 Uncoupling protein-2 prevents neuronal death and diminishes brain dysfunction after stroke and brain trauma. Nature Medicine 9 1062-1068.

McEnery MW, Dawson TD, Verma A, Gurley D, Colombini M \& Snyder SH 1993 Mitochondrial voltage-dependent anion channel: immunochemical immunohistochemical characterisation in rat brain. Journal of Biological Chemistry 268 23289-23296.

Mostyn A, Bispham J, Pearce S, Evens Y, Raver N, Keisler DH, Webb R, Stephenson T \& Symonds ME 2002 Differential effects of leptin on thermoregulation and uncoupling protein abundance in the neonatal lamb. FASEB Journal 16 1438-1440.

Mostyn A, Pearce S, Budge H, Elmes M, Forehead AJ, Fowden AL, Symonds ME \& Stephenson T 2003a Influence of cortisol on adipose tissue development in the fetal sheep during late gestation. Journal of Endocrinology 176 23-30.
Mostyn A, Wilson V, Dandrea J, Yakubu DP, Budge H, Alves-Guerra MC, Pecqueur C, Miroux B, Symonds ME \& Stephenson T 2003b Ontogeny and nutritional manipulation of mitochondrial protein abundance in adipose tissue and the lungs of postnatal sheep. British Journal of Nutrition 90 323-328.

Mostyn A, Litten JC, Perkins KS, Alves-Guerra MC, Pecqueur C, Miroux B, Symonds ME \& Clarke L 2004 Influence of genotype on the differential ontogeny of uncoupling protein 2 and 3 in subcutaneous adipose tissue and muscle in neonatal pigs. Journal of Endocrinology 183 121-131.

Nedergaard J \& Cannon B 2003 The 'novel' 'uncoupling' proteins UCP2 and UCP3: what do they really do? Pros and cons for suggested functions. Experimental Physiology 88 65-84.

Negre-Salvayre A, Hirtz C, Carrera G, Cazenave R, Troly M, Salvayre R, Penicaud L \& Casteilla L 1997 A role for uncoupling protein-2 as a regulator of mitochondrial hydrogen peroxide generation. FASEB Journal 11 809-815.

Nikolajev K, Heinonen K, Hakulinen A \& Lansimies E 1998 Effects of intrauterine growth retardation and prematurity on spirometric flow values and lung volumes at school age in twin pairs. Pediatric Pulmonology 25 367-370.

Olver RE, Walters DV \& Wilson MS 2004 Developmental regulation of lung liquid transport. Annual Review of Physiology 66 77-101.

Ookawara T, Suzuk K, Haga S, Ha S, Chung KS, Toshinai K, Hamaoka T, Katsumura T, Takemasa T, Mizuno M et al. 2002 Transcription regulation of gene expression in human skeletal muscle in response to endurance training. Research Communications in Molecular Pathology and Pharmacology 111 41-54.

Ozdemir A, Brown MA \& Morgan WJ 1997 Markers and mediators of inflammation in neonatal lung disease. Pediatric Pulmonology 23 292-306.

Painter R, Roseboom T, Patrick M, Bossuyt P, Osmond C, Barker D \& Bleker O 2005 Adult mortality at age 57 after prenatal exposure to the Dutch Famine. European Journal of Epidemiology 20 673-676.

Paradis E, Clavel S, Bouillaud F, Ricquier D \& Richard D 2003 Uncoupling protein 2: a novel player in neuroprotection. Trends in Molecular Medicine 9 522-525.

Pecqueur C, Alves-Guerra M-C, Gelly C, Lévi-Meyrueis C, Couplan E, Collins S, Ricquier D, Bouillaud F \& Miroux B 2001 Uncoupling protein-2: in vivo distribution, induction upon oxidative stress and evidence for translational regulation. Journal of Biological Chemistry 276 8705-8712.

Phillippe M 1983 Fetal catecholamines. American Journal of Obstetrics and Gynecology 146 840-855.

Prakash YS, Fournier M \& Sieck GC 1993 Effects of prenatal undernutrition on developing rat diaphragm. Journal of Applied Physiology 75 1044-1052.

Rae MT, Rhind SM, Kyle CE, Miller DW \& Brooks AN 2002 Maternal undernutrition alters triiodothyronine concentrations and pituitary response to GnRH in fetal sheep. Journal of Endocrinology 173 449-455.

Rajatapiti P, Kester MH, de Krijger RR, Rottier R, Visser TJ \& Tibboel D 2005 Expression of glucocorticoid, retinoid, and thyroid hormone receptors during human lung development. Journal of Clinical Endocrinology and Metabolism 90 4309-4314.

Rayburn WF, Beynen A \& Brinkman DL 1981 Umbilical cord length and intrapartum complications. Obstetrics and Gynecology 57 450-452.

Rees S, Ng J, Dickson K, Nicholas T \& Harding R 1991 Growth retardation and the development of the respiratory system in fetal sheep. Early Human Development 26 13-27.

Ricquier D \& Bouillaud F 2000 The uncoupling protein homologues: UCP1, UCP2, UCP3, StUCP and AtUCP. Biochemical Journal 345 161-179.

Robinson PM, Comline RS, Fowden AL \& Silver M 1983 Adrenal cortex of fetal lamb: changes after hypophysectomy and effects of synacthen on cytoarchitecture and secretory activity. Quarterly Journal of Experimental Physiology 68 15-27. 
Roseboom TJ 2000 Prenatal exposure to the Dutch Famine and health in later life. PhD Thesis, University of Amsterdam.

Roseboom TJ, van der Meulen JHP, Osmond C, Barker DJP, Ravelli ACJ \& Blecker OP 2000a Plasma lipid profile in adults after perinatal exposure to famine. American Journal of Clinical Nutrition 72 1101-1106.

Roseboom TJ, van der Meulen JHP, Osmond C, Barker DJP, Ravelli ACJ, Shroeder-Tanka JM, van Montfrans GA, Michels RPJ $\&$ Blecker OP $2000 b$ Coronary heart disease in adults after perinatal exposure to famine. Heart 84 595-598.

Sahebjami H 1993 Nutrition and lung structure and function. Experimental Lung Research 19 105-124.

Sapolsky R, Krey L \& McEwen B 1984 Stress down-regulates corticosterone receptors in a site-specific manner in the brain. Endocrinology 114 287-292.

Seckl JR, Morton NM, Chapman KE \& Walker BR 2004 Glucocorticoids and 11 beta-hydroxysteroid dehydrogenase in adipose tissue. Recent Progress in Hormone Research 59 359-393.

Shinohara Y, Ishida T, Hino M, Yamazaki N, Baba Y \& Terada H 2000 Characterization of porin isoforms expressed in tumor cells. European Journal of Biochemistry 267 6067-6073.

Smith L \& Anderson J 1992 Oxygen-induced lung damage. Relationship to lung mitochondrial glutathione levels. American Review of Respiratory Disease 146 1452-1457.

Stein CE, Kumaran K, Fall CH, Shaheen SO, Osmond C \& Barker DJ 1997 Relation of fetal growth to adult lung function in south India. Thorax 52 895-899.

Stewart PM \& Krozowski ZS 1999 11ß-Hydroxysteroid dehydrogenase. Vitamins and Hormones 57 249-324.

Sun X \& Zemel MB 2004 Role of uncoupling protein 2 (UCP2) expression and 1 alpha, 25-dihydroxyvitamin $\mathrm{D}_{3}$ in modulating adipocyte apoptosis. FASEB Journal 18 1430-1432.

Svec F \& Rudis M 1981 Glucocorticoids regulate the glucocorticoid receptor in the AtT-20 cell. Journal of Biological Chemistry 256 5984-5987.

Symonds ME \& Clarke L 1996 Influence of thyroid hormones and temperature on adipose tissue development and lung maturation. Proceedings of the Nutrition Society 55 567-575.

Symonds ME, Lomax MA, Kenward MG, Andrews DC \& Johnson PJ 1993 Effect of the prenatal maternal environment on the control of breathing during non-rapid eye movement sleep in the developing lamb. Journal of Developmental Physiology 19 43-50.

Symonds ME, Bird JA, Clarke L, Gate JJ \& Lomax MA 1995 Nutrition, temperature and homeostasis during perinatal development. Experimental Physiology 80 907-940.

Symonds ME, Mostyn A, Pearce S, Budge H \& Stephenson T 2003 Endocrine and nutritional regulation of fetal adipose tissue development. Journal of Endocrinology 179 293-299.
Thomas AL, Krane EJ \& Nathanielsz PW 1978 Changes in the fetal thyroid axis after induction of premature parturition by low dose continuous intravascular cortisol infusion to the fetal sheep at 130 days of gestation. Endocrinology 103 17-23.

Thulbeck WM 1982 Postnatal human lung growth. Thorax 37 564-571.

Tsuchiya T, Shimizu H, Horie T \& Mori M 1999 Expression of leptin receptor in lung: leptin as a growth factor. European Journal of Pharmacology 365 273-279.

Tu N, Chen H, Winnikes U, Reinert I, Marmann G, Pirke KM \& Lentes KU 1999 Molecular cloning and functional characterization of the promoter region of the human uncoupling protein-2 gene. Biochemical and Biophysical Research Communications 265 326-334.

Voehringer DW, Hirschberg DL, Xiao J, Lu Q, Roederer M, Lock CB, Herzenberg LA, Steinman L \& Herzenberg LA 2000 Gene microarray identification of redox and mitochondrial elements that control resistance or sensitivity to apoptosis. PNAS 97 2680-2685.

Wallace MJ, Hooper SB \& Harding R 1996 Role of the adrenal glands in the maturation of lung liquid secretory mechanisms in fetal sheep. American Journal of Physiology 270 R33-R40.

Wheeler T \& Greene K 1975 Fetal heart rate monitoring during breech labour. British Journal of Obstetrics and Gynaecology 82 208-214.

Whorwood CB, Firth KM, Budge H \& Symonds ME 2001 Maternal undernutrition during early- to mid-gestation programmes tissue-specific alterations in the expression of the glucocorticoid receptor, $11 \beta$-hydroxysteroid dehydrogenase isoforms and type 1 angiotensin II receptor in neonatal sheep. Endocrinology 142 2854-2864.

Wignarajah D, Cock ML, Pinkerton KE \& Harding R 2002 Influence of intrauterine growth restriction on airway development in fetal and postnatal sheep. Pediatric Research 51 681-688.

Wu S, Klein AH, Chopra I \& Fisher DA 1978 Alterations in tissue thyroxine- 5 -monodeiodinating activity in the perinatal period. Endocrinology 103 235-239.

Xiao H, Massaro D, DeCarlo Massaro G \& Clerch LB 2004 Expression of lung uncoupling protein-2 mRNA is modulated developmentally and by caloric intake. Experimental Biology and Medicine 229 479-485.

Yakubu DP 2005 Maternal nutrition and the programming of mitochondrial proteins. PhD Thesis, University of Nottingham.

Received in final form 15 December 2005

Accepted 5 January 2006

Made available online as an Accepted Preprint

19 January 2006 